\title{
Management of Chilli Leaf Curl Virus Disease in the Coastal Zone of Odisha through Integrated Approach
}

\author{
S. Sarkar*, G.S. Sahu, S. Das, S.K. Dash, A. Nandi and A. Patnaik \\ AICRP on Vegetable Crops, Orissa University of Agriculture \& Technology, \\ Bhubaneswar-751003, India \\ *Corresponding author
}

\section{Keywords}

Chilli, Development, Integrated approach, Chilli leaf curl virus

Article Info

Accepted:

04 March 2018

Available Online:

10 April 2018

\section{A B S T R A C T}

Chilli crop is attacked by a large number of pathogens but heavy crop loss is caused due to leaf curl disease of chilli caused by Begomovirus belonging to the family Geminiviridae is transmitted by viruliferous whitefly (Bemisiatabaci Genn.). In India, Senanayake et al., (2006) have reported first time chilli leaf curl virus on chilli crop and crop loss has been estimated up to $80 \%$ in some parts of India (Nigam et al., 2015). Therefore, an integrated approach involving physical, botanical and chemical module has been formulated to manage the chilli leaf curl virus disease during three consecutive years from 2014-15, 2015-16 and 2016-17 at AICRP on Vegetable Crops, OUAT, Bhubaneswar during Rabi season. Our results showed that the chilli leaf curl virus disease could effectively be reduced by all the treatments through integration of physical, botanical and chemical management practices since they were statistically equally effective over control in respect of reducing disease incidence and white fly population/plant and fruit yield $(\mathrm{q} / \mathrm{ha})$. But while considering cost of different treatments and net income over the years, the pooled data revealed that the maximum net return (Rs.1,36,909/-) was obtained with integrated management practices (T3) with substantially low percent disease incidence (6.9\%) and white fly population/plant (0.99/plant) while minimum net return was recorded in T6 (Rs.25,261/-). Similarly, the cost benefit ratio was found to be the maximum in integrated management practices (T3) (2.44) and the minimum B: C was recorded in T6 (1.29). So, chilli growers who are facing problem from chilli leaf curl disease can easily grow their crop by adopting the technologies involving spray of Imidacloprid 70\% WG @ 2 g/15 1+ Neem oil @ $2 \mathrm{ml} / \mathrm{l}$ at 7 days interval till fruit formation coupled with border crop of maize (Two rows of maize at 15 days prior transplanting) and use of Agri silver mulch because this integrated disease management practice (T3) gave maximum net return (Rs.1,36,909/-) with highest B:C ratio (2.44).

\section{Introduction}

Chilli (Capsicum annuum L.) is an important spice crop grown for its fruits, which are used in green as well as ripe dried form for its pungency. Chilli belongs to the genus
Capsicum family Solanaceae. There are mainly four cultivated Capsicum species and they are originated from South America. Commercial cultivation of chilli is mostly confined to the tropical regions of the world, since it requires long and warm season for its 
growth and development. Chilli is known from prehistoric remains in Peru and was widely cultivated in Central and South America in early times. It was first introduced in India by Portuguese towards the end of 15 th century. Now-a-day's chilli has become an important crop all over India. It is used very widely in culinary, pharmaceutical and beverage industries throughout the world. It is an important condiment used for imparting pungency and colour to the food being rich in vitamin $\mathrm{C}, \mathrm{A}, \mathrm{B}$, oleoresin and red pigment. As the climatic conditions of India are diverse, chillies are grown at different times in different ecological zones in each province, but its cultivation is mostly concentrated in the southern states viz., Andhra Pradesh, Karnataka, Maharashtra and Tamil Nadu, occupying nearly 75 per cent of total area under chilli in India, which is the second largest exporter of chilli in the world and is exported in the form of whole dried fruits, fresh chillies, chilli powder and oleoresins to south Asian countries, USA and Canada. In India, chilli is being grown on an area of 7.20 lakh hectares with the production of 12.50 lakh tonnes (Anon., 2008).Though the area under chilli cultivation in Odisha is more, its production is low as compared to the other states because of the poor management of economically important pest and diseases. Chilli pepper is naturally susceptible to a wide range of viruses in all South Asian countries including India. 22viruses infecting chilli, mosaic and leaf curl disease are the most devastating (Wagner, Georg, 2004) caused by Begomovirus belonging to the family Geminiviridae is transmitted by viruliferous whitefly (Bemisiatabaci Genn.). The chilli leaf curl virus (ChiLCV) disease on chilli was first reported in Pakistan by Shih et al., (2003) and in India by Senanayake et al., (2006) and crop loss has been estimated up to $80 \%$ in some parts of India (Nigam et al., 2015). Leaf curl or yellowing symptoms, typical of those caused by Begomovirus infection, cotton leaf curl Multan virus (CLCuMV) by Hussain et al., (2004) and Pepper yellow leaf curl Indonesia virus (PepYLCIV) (Tsai et al.,2006) have been associated with chilli leaf curl in Pakistan and Indonesia respectively. In India, tomato leaf curl New Delhi virus (ToLCNDV) was recently shown to be associated with chilli leaf curl disease occurring in Lucknow (Khan et al., 2006).Exclusive reliance on insecticides as a control strategy against these biotic stresses has resulted in several undesirable effects like pesticide pollution, resurgence of secondary pests, insecticide resistance, elimination of beneficial fauna and different human health hazards. Although, insecticidal interventions bring down the pest damage which they have led to problem of pesticide residues in fruits (Joia et al., 2001). Resistance management is a key consideration for these biotic stresses in chillies. The most common methods of preventing resistance to insecticides include minimizing the number of applications per season of 'at-risk' products, using insecticides with diverse modes of action and applying them in alternation or as mixtures. It has also been reported that the use of physical barrier can protect the crop against ToLCV disease (Crop life, 2008).

Use of agri silver mulch is indeed highly efficient in reflecting the heat along with light which drives away the white fly. But these protections alone may not sufficiently protect against leaf curl disease since some whiteflies are still able to enter main field through gaps in entrances and on personnel. Managing the diseases through chemicals alone is not satisfactory in view of the environmental concerns and cost benefit ratio. In this context, to manage the disease effectively a field experiment was undertaken to find out an integrated disease management strategies that is through the use insecticides with neem oil coupled with border crop of maize and use of Agri silver mulch for the management of vector borne chilli leaf curl viral disease 


\section{Materials and Methods}

\section{Experimental site and plants growing}

The experiment was conducted in a randomized block design with four replications under All India Coordinated Research Project on Vegetable Crops at Central Research Station OUAT, Bhubaneswar (East and SE Coastal Plain Zone, $20^{\circ} 15^{\prime} \mathrm{N}$ latitude and $85^{\circ} 52^{\prime}$ E longitude) during the Rabi season of three consecutive years of 2014-15, 2015-16 and 2016-17.Treated seeds of chilli (Utkal Ava) with Imidacloprid70\% WG @ 8 gm/ kgwere sown in well prepared nursery beds mixed with well rotten FYM and neem cake @ $1 \mathrm{Kg} /$ sq.mt. Thirty days old seedlings which were sprayed with Cyazypyr (Cyantraniliprole $10.26 \%$ ) @ 1.8 mi $/ 1$ 2-3 days before transplanting and seedling root dip of Imidacloprid @ $0.5 \mathrm{ml} / \mathrm{l}$ transplanted to the main field previously surrounded with 2 rows of maize sown 15 days before transplanting of chilli seedlings accommodating 54 plants in individual plot measuring $3.0 \mathrm{mx} 2.7 \mathrm{~m}$ during the Rabi season in each year. Plots were divided into six treatment combinations following Randomized Block Design with four replications and different cultural managements were followed in time.

\section{Treatment combinations}

Application of neem cake @ $1.0 \mathrm{~kg} / \mathrm{sq} \cdot \mathrm{mt}$ in the seed bed, spraying of Cyazypyr (Cyantraniliprole 10.26\%) @ 1.8 mi/l 2-3 days before transplanting, seed treatment with Imidacloprid 70\%WG @ 8 gm/ kg, seedling root dip of Imidacloprid @ $0.5 \mathrm{ml} / 1$ and growing of two rows of maize as a border crop in the main were common for all treatments except control plot.This experiment includes six treatments like $\mathrm{T}_{1}$ - $\mathrm{T} 0+$ spray of Acephate 75 SP @1.5 g/l + Neem oil 1500 ppm @ 2 $\mathrm{ml} / \mathrm{l}$ at 7 days interval till fruit formation, $\mathrm{T}_{2}$ -
T0 + spray of Fipronil5 SC @ 1.0 ml/l + Neem oil 1500 ppm @ $2 \mathrm{ml} / \mathrm{l}$ at 7 days interval till fruit formation, $\mathrm{T}_{3^{-}} \mathrm{T} 0+$ spray of Imidacloprid70\%WG @ 2 g/15 1 + Neem oil 1500ppm@ $2 \mathrm{ml} / \mathrm{l}$ at 7 days interval till fruit formation, $\mathrm{T}_{4^{-}} \mathrm{T} 0+$ spray of Cyazypyr (Cyantraniliprole 10.26\%) @ $1.8 \mathrm{ml} / 1$ at 7 days interval till fruit formation and $\mathrm{T}_{5}-\mathrm{T} 0+$ spray rotation of $\mathrm{T} 1+\mathrm{T} 2+\mathrm{T} 3+\mathrm{T} 4$ sequential application at 7 days interval till fruit formation,

\section{Experimental data recording}

The incidence of chilli leaf curl disease was recorded from all the individual plot by recording the infected plant one day before each spray and finally percentage of leaf curl virus disease incidence was calculated by using the following formula.

PI $=\frac{\text { Number of infected plants } / \text { plot }}{\text { Total no of plants observed/plot }} \times 100$

Five plants were selected randomly for each treatment and white fly population/plant was counted one day before each spray. Marketable fruits (excluding disease and insect damage fruits) of the periodical harvests from the individual plot were counted and weighed to express marketable fruit yield per plot $(\mathrm{kg})$ and then it was converted to marketable fruit yield (quintal) in hectare.

\section{Economic analysis}

The cost benefit ratio (B:C) over the control was worked out separately considering different treatment combination on the basis of existing prices of inputs, hired labour wages (Rs.213.5/- per man days), market price of dried chilli fruit (Rs.10000/- per quintal) during the time of this study Table 1 . Effect of different treatments on chilli leaf curl disease incidence at different day intervals (Pooled 2014-15, 2015-16 and 2016-17) 


\section{Results and Discussion}

\section{Effect of treatments on disease incidence}

Attempts were made to develop integrated management strategies an experiment was conducted under All India Coordinated Research Project on Vegetable Crops at Horticulture Research Station OUAT, Bhubaneswar (East and SE Coastal Plain Zone, $20^{\circ} 15^{\prime} \mathrm{N}$ latitude and $85^{\circ} 52^{\prime}$ E longitude) with four chemicals plus with one bio pesticide viz. Acephate 75\% SP, Fipronil 5 $\%$ SC, Imidacloprid 70 \%WG, Cyazypyr (Cyantraniliprole 10.26\%) and neem oil 1500 ppm coupled with border crop of maize and use of Agri silver mulch for the management of vector borne chilli leaf curl viral disease during the Rabi season of three consecutive years of 2014-15, 2015-16 and 2016-17.

Disease incidences of chilli leaf curl virus were recorded at 7, 14, 21, 28,35,42,49 and 56 days after transplanting and fruit yield was calculated from cumulative harvest. The results of percent disease incidence of chilli leaf curl disease at different days intervals after transplanting (DAT) are presented in Table 1 . The present investigation revealed that in general all the treatment combinations had substantial positive effects on the reduction of percent disease incidence over control (Figure 1).

Three years pooled data on the incidence of chilli leaf curl virus disease it is clearly indicated that the lowest disease incidence of $4.9 \%$ was recorded in plots received integrated management treatment (T5) followed by the plots (T4), (T3), (T1) and (T2) with percentage disease incidence of 5.4, 6.9, 8.5 and 8.6 percent respectively and the treatments were equally effective in reducing the disease incidence over the control plot because the treatments were statistically at par with each others. However, the control plot recorded maximum percent disease incidence (29.5\%). Among the management practices, the maximum reduction in chilli leaf curl virus disease was found in integrated management T5 (83.38\%) followed by T4 (81.70\%) and T3 $(76.61 \%)$.

\section{Effect of treatments on white fly population/plant}

The results of white fly population/plant of chilli at different days intervals after transplanting (DAT) are presented in Table 2.

Data obtained from the Table 2. Clearly indicated that all the treatments positively lowered the white fly population/plant which is the vector for spreading of chilli leaf curl virus disease. Three years pooled data showed similar trends in reducing vector population in treatments wise as observed in case of reduction of disease incidence in different treatments i.e. the lowest white fly population/plant (0.71) was recorded in plots received integrated management treatment (T5) followed by the plots (T4), (T3), (T1) and (T2) with white fly population/plant of 0.77 , $0.99,1.37$ and 1.06 respectively and the treatments were statistically at par in respect checking white fly.

Effective restriction in vector population at various growth stages of the crop is crucial for successful implementing viral disease control programs. Since the chilli leaf curl virus disease is transmitted by whitefly, the movement of whitefly was restricted by heating back from the barrier crop which was $90-100 \mathrm{~cm}$ in height by this time and use of white Agri polythene mulch having reflecting activity of light might have caused low level of vector population and low level of disease incidence. In this backdrop, the integrated management practices involving different chemicals with neem oil could reduce whitefly populations substantially in chilli plots. 
Table.1 Effect of different treatments on incidence of chilli leaf curl virus disease (\%) at different day intervals (Pooled 2014-15, 2015-16 and 2016-17)

\begin{tabular}{|c|c|c|c|c|c|c|c|c|}
\hline Treatments & $\begin{array}{l}7 \\
\text { DAT }\end{array}$ & 14 DAT & 21 DAT & $28 \mathrm{DAT}$ & 35 DAT & $42 \mathrm{DAT}$ & 49 DAT & $56 \mathrm{DAT}$ \\
\hline $\begin{array}{l}\mathrm{T}_{1} \text { - T0 + spray of Acephate } \\
75 \mathrm{SP} @ 1.5 \mathrm{~g} / \mathrm{l}+\text { Neem oil @ } \\
2 \mathrm{ml} / \mathrm{l} \text { at } 7 \text { days interval till } \\
\text { fruit formation }\end{array}$ & 0.00 & 0.00 & 0.00 & $1.5(4.23)$ & $2.5(5.42)$ & $4.2(11.48)$ & $6.7(14.80)$ & $8.5(16.77)$ \\
\hline $\begin{array}{l}\mathrm{T}_{2^{-}} \mathrm{T} 0+\text { spray of Fipronil } 5 \\
\mathrm{SC} @ 1.0 \mathrm{ml} / \mathrm{l}+\text { Neem oil @ } 2 \\
\mathrm{ml} / \mathrm{l} \text { at } 7 \text { days interval till } \\
\text { fruit formation }\end{array}$ & 0.00 & 0.00 & 0.00 & $1.7(4.37)$ & $2.8(7.17)$ & $4.7(12.0)$ & $7.0(15.04)$ & $8.6(16.51)$ \\
\hline $\begin{array}{l}\text { T3- T0 + spray of } \\
\text { Imidacloprid 70\% WG @ } 2 \\
\text { g/15 1 + Neem oil @ } 2 \text { ml/ at } \\
7 \text { days interval till fruit } \\
\text { formation }\end{array}$ & 0.00 & 0.00 & 0.00 & $1.1(2.88)$ & $2.3(5.63)$ & $3.7(10.31)$ & $5.6(13.47)$ & $6.9(14.55)$ \\
\hline $\begin{array}{l}\mathrm{T}_{4-} \text { - T0 + spray of Cyazypyr } \\
\text { (Cyantraniliprole } 10.26 \% \text { ) } \\
\text { @ } 1.8 \mathrm{ml} \text { / at } 7 \text { days interval } \\
\text { till fruit formation }\end{array}$ & 0.00 & 0.00 & 0.00 & $0.0(0.00)$ & $1.5(3.41)$ & $2.5(7.36)$ & $3.9(10.64)$ & $5.4(12.96)$ \\
\hline $\begin{array}{l}\mathrm{T}_{5^{-}} \mathrm{T} 0+\text { spray rotation of } \\
\mathrm{T} 1+\mathrm{T} 2+\mathrm{T} 3+\mathrm{T} 4 \\
\text { sequential application at } 7 \\
\text { days interval till fruit } \\
\text { formation }\end{array}$ & 0.00 & 0.00 & 0.00 & $0.5(1.76)$ & $1.2(3.09)$ & $3.2(9.50)$ & $4.7(12.04)$ & $4.9(12.45$ \\
\hline T $_{6^{-}}$Control (No spray) & 0.00 & 0.00 & $6.7(10.56)$ & $15.5(15.64)$ & $20.5(19.30)$ & $24.1(29.32)$ & $25.9(30.55)$ & $29.5(32.88)$ \\
\hline $\mathrm{SE}(\mathrm{m})+$ & - & - & & 1.95 & 2.21 & 2.24 & 1.54 & 1.52 \\
\hline CD (0.05) & - & - & & 5.94 & 6.74 & 6.83 & 4.69 & 4.62 \\
\hline CV (\%) & - & - & & 56.91 & 36.48 & 31.13 & 17.41 & 15.71 \\
\hline
\end{tabular}


Table.2 Effect of different treatments on white fly population per plant of chilli at different day intervals (Pooled 2014-15, 2015-16 and 2016-17)

\begin{tabular}{|c|c|c|c|c|c|c|c|c|}
\hline Treatments & 7 DAT & 14 DAT & $21 \mathrm{DAT}$ & 28 DAT & 35 DAT & $42 \mathrm{DAT}$ & 49 DAT & 56 DAT \\
\hline $\begin{array}{l}\mathrm{T}_{1}-\mathrm{T} 0+\text { spray of } \\
\text { Acephate @ } 1.5 \mathrm{~g} / \mathrm{l}+ \\
\text { Neem oil @ } 2 \mathrm{ml} / \mathrm{l} \text { at } 7 \\
\text { days interval till fruit } \\
\text { formation }\end{array}$ & $0.89(1.18)$ & $1.22(1.30)$ & $0.91(1.18)$ & $1.19(1.30)$ & $1.14(1.28)$ & $1.07(1.25)$ & $1.25(1.32)$ & $1.37(1.37)$ \\
\hline $\begin{array}{l}\mathrm{T}_{2-} \mathrm{T} 0+\text { spray of } \\
\text { Fipronil @1.0 ml// + } \\
\text { Neem oil @ } 2 \mathrm{ml} / \mathrm{l} \text { at } 7 \\
\text { days interval till fruit } \\
\text { formation }\end{array}$ & $0.79(1.13)$ & $1.09(1.20)$ & $0.88(1.16)$ & $1.13(1.27)$ & $1.14(1.27)$ & $1.05(1.24)$ & $1.12(1.26)$ & $1.06(1.23)$ \\
\hline $\begin{array}{l}\mathrm{T}_{3} \text {-T0 + spray of } \\
\text { Imidacloprid @ } 2 \text { g/15 I } \\
+ \text { Neem oil @ } 2 \text { ml/l at } 7 \\
\text { days interval till fruit } \\
\text { formation }\end{array}$ & $0.70(1.09)$ & $0.89(1.18)$ & $0.79(1.13)$ & $0.97(1.21)$ & $0.99(1.22)$ & $0.88(1.17)$ & $0.94(1.19)$ & $0.99(1.22)$ \\
\hline $\begin{array}{l}\mathrm{T}_{4} \text { - T0 + spray of } \\
\text { Cyazypyr @ } 1.8 \mathrm{ml} / \mathrm{l} \text { at } \\
7 \text { days interval till fruit } \\
\text { formation }\end{array}$ & $0.60(1.05)$ & $0.65(1.07)$ & $0.58(1.04)$ & $0.82(1.15)$ & $0.82(1.14)$ & $0.73(1.30)$ & $0.76(1.12)$ & $0.77(1.12)$ \\
\hline $\begin{array}{l}\mathrm{T}_{5^{-}} \mathrm{T} 0+\mathrm{spray} \text { rotation } \\
\text { of } \mathrm{T} 1+\mathrm{T} 2+\mathrm{T} 3+\mathrm{T} 4 \\
\text { sequential application } \\
\text { at } 7 \text { days interval till } \\
\text { fruit formation } \\
\end{array}$ & $0.57(1.03)$ & $0.65(1.07)$ & $0.54(1.02)$ & $0.76(1.12)$ & $1.82(1.11)$ & $0.68(1.08)$ & $0.73(1.10)$ & $0.71(1.10)$ \\
\hline $\mathrm{T}_{6}-$ Control & $1.86(1.52)$ & $2.2(1.76)$ & $2.72(1.79)$ & $3.08(1.90)$ & $3.26(1.99)$ & $3.45(1.98)$ & $3.55(2.01)$ & $3.69(2.05)$ \\
\hline $\mathbf{S E}(\mathbf{m})+$ & 0.34 & 0.3 & 0.25 & 0.22 & 0.19 & 0.18 & 0.19 & 0.18 \\
\hline CD (0.05) & 1.04 & 0.91 & 0.76 & 0.68 & 0.59 & 0.55 & 0.59 & 0.57 \\
\hline $\mathrm{CV}(\%)$ & 13.38 & 12.83 & 9.87 & 8.61 & 8.33 & 7.76 & 7.79 & 7.43 \\
\hline
\end{tabular}


Table.3 Effect of different treatments on red ripe fruit yield and economics of chilli (Pooled 2014-15, 2015-16 and 2016-17)

\begin{tabular}{|l|l|l|l|l|}
\hline Treatment & Yield(q/ha) & Cost of cultivation(Rs.) & Gross income(Rs.) & B:C \\
\hline $\mathrm{T}_{1}$ & 72.2 & 93442.00 & 216500.00 & 2.31 \\
\hline $\mathrm{T}_{2}$ & 72.0 & 94128.00 & 216100.00 & 2.29 \\
\hline $\mathrm{T}_{3}$ & 77.2 & 94591.00 & 231500.00 & 2.44 \\
\hline $\mathrm{T}_{4}$ & 80.8 & 158032.00 & 242400.00 & 1.53 \\
\hline $\mathrm{T}_{5}$ & 81.5 & 109549.00 & 253158.00 & 2.31 \\
\hline $\mathrm{T}_{6}$ & 41.9 & 85684.00 & 110945.00 & 1.29 \\
\hline $\mathrm{SE}(\mathbf{m})+$ & 3.25 & - & - & - \\
\hline $\mathrm{CD}(\mathbf{0 . 0 5})$ & 9.80 & - & - & - \\
\hline $\mathrm{CV}(\%)$ & 9.68 & - & - & - \\
\hline
\end{tabular}
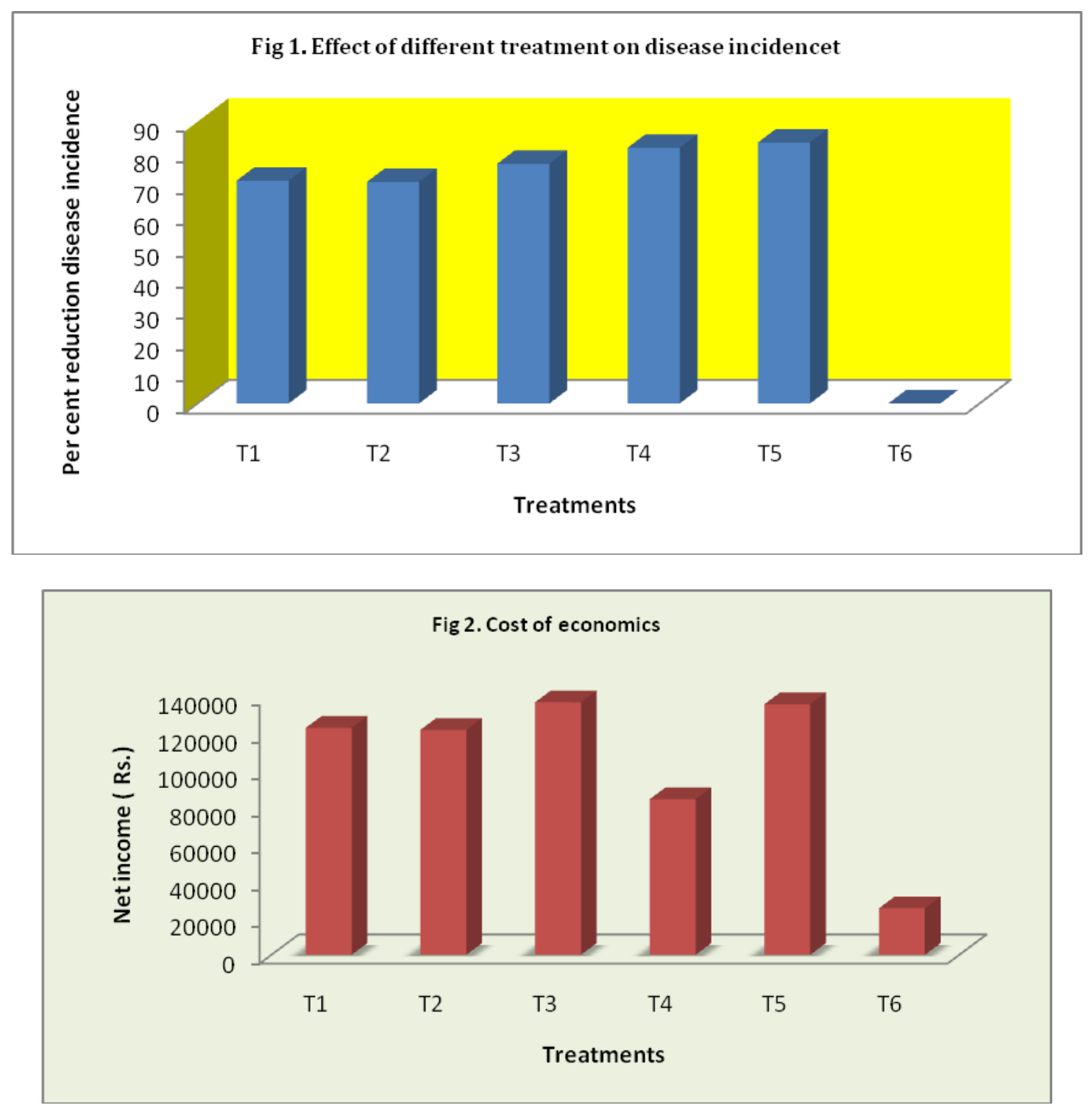


\section{Effect of treatments on marketable yield}

Marketable yield of each treatment was calculated after several pickings in three consecutive years and presented in Table 3 . The pooled data showed that fruit yield was significantly higher in all treatment combinations (72.0 to $81.5 / \mathrm{ha}$ ) compared to control $(41.9 \mathrm{q} / \mathrm{ha})$ indicating the positive effects of different treatments on increase in yield of chilli. The maximum fruit yield $(81.8 \mathrm{q} / \mathrm{ha})$ was recorded in plots receiving integrated management practices (T5) followed by T4 (80.0q/ha), T3 (77.2q/ha), T2 (72.0q/ha) and T1 (72.2q/ha) and the treatments were statistically at par with each other. The percentage increase in marketable yield over control ranged from $71.8 \%$ (T2) to $94.5 \%$ (T5). The integrated management practices could significantly reduce the incidence of chilli leaf curl disease at right stages that result profuse growth of the crop and ultimately increase the maximum tune of marketable fruit yield compared to untreated control. On the other hand, susceptibility of the crop against chilli leaf curl disease in untreated control exhibited weak growth of the crop resulting very low yield.

\section{Economics analysis of different treatments}

The cost of cultivation was computed separately considering different treatment combination on the basis of existing prices of inputs, hired labour wages (Rs.213.5/- per man days), market price of dried chilli fruit (Rs.10000/- per quintal)during the time of this study and presented in Table 3 . Results that the cost of chilli production was highly influenced by different treatment combinations. Three years pooled data revealed that the maximum net return (Rs.136909/-) was obtained with integrated management practices (T3) and the minimum net return was recorded in T6 (Rs.25261/-) which is presented in Figure 2. Similarly, the cost benefit ratio was found to be the maximum in integrated management practices (T3) (2.44) and the minimum B: C was recorded in T6 (1.29). This was happened due to high excess yield recorded in plots received proper integrated disease management practice (T3). Considering the cost of cultivation of different treatments, it is clearly indicated that $\mathrm{T} 3$ recorded the highest net return with highest $\mathrm{B}$ : $\mathrm{C}$ ratio though lowest disease incidence and white fly population/plant was recorded in T5. Our results well supported by observations of previous workers (Mullins et al., 1993, Ahmed et al., 2001 and Cahill et al., 1996) and they recommended neonicotinoid group of insecticides (thiomethoxam, imidacloprid and dinotefuron) to reduce whitefly populations in order to save tomato plants against leaf curl virus diseases.

Therefore, it can be concluded from the present investigation that that the chilli leaf curl virus disease is the major hindrance for chilli cultivation particularly in the Coastal zone of Odisha, could effectively be reduced in a sustainable manner through integration of physical, botanical and chemical management practices. Further it was revealed from the present study that the treatments were statistically equally effective in respect of reducing disease incidence by lowering the vector population over the control but while considering cost of different treatments and net income then it can be concluded that among the treatments T3 performed better than the other treatments. So, chilli growers who are facing problem from chilli leaf curl disease can easily grow their crop by adopting the technologies involving spray of Imidacloprid 70\% WG @ 2 g/15 1 + Neem oil @ $2 \mathrm{ml} / 1$ at 7 days interval till fruit formation coupled with border crop of maize (Two rows of maize at 15 days prior transplanting) and use of Agri silver mulch $\left(\mathrm{T}_{3}\right)$ because this integrated disease management practice(T3) 
gave maximum net return (Rs.136909/-) with highest B: C ration (2.44).

\section{References}

Ahmed, N. E., Kanan, H. O., Sugimoto, Y., Ma, Y. Q., Inanaga, S., 2001, Effect of imidacloprid on incidence of tomato yellow leaf curl virus. Journal of Plant Diseases and Protection, 85(1): 84-87.

Anonymous, 2008, Area and Production Statistics of Arecanut and Spices, Directorate of Arecanut and Spices Development, Calicut, Kerala, pp. 1110.

Anonymous, 2008, Crop Life: Fungicide Resistance Management Strategies. Crop Life Australia Limited: Canberra ACT.

Cahill, M., Denholm, I., Byrne, F. J., Devonshire, A. L., 1996, Insecticide resistance in Bemisia tabaci-current status and implications for management. Brighton Crop Protection Conference: Pests and Diseases. British Crop Protection Council, UK, pp. 75-80.

Hussain, M., Mansoor, S., Zafar, Y. and Briddon, R. W., 2004, First report of Tomato leaf curl New Delhi virus affecting on chilli pepper in Pakistan. Plant Pathol., 53 :794.

Joia, B. S., Jaswinder Kaur and Udean, A. S., 2001, Persistence of ethion residues in green chilli. Proc. Second Symp. Int.
Pest Mgmt. Crops, Indian Inst. Horti. Res., Bangalore, 19 October, pp. 174175.

Khan, M. S., Raj, S. K., Singh, R., First report of Tomato leaf curl New Delhi virus infecting chilli in India. Plant Pathology, 2006; 55: 289. (First published online: New Disease Reports 11.

Mullins, J. W., Engle, C. E., 1993, Imidacloprid (BAY NTN 33893): a novel chemistry for sweet potato whitefly control in cotton. In: Herber DJ, Richter DA (Eds.), Proceedings, Symposium: Beltwide Cotton Conferences. National Cotton Council, Memphis, TN, pp. 719-720.

Nigam, K., Suhail, S., Verma, Y., Singh, V. and Gupta, S., 2015. Molecular Characterization of Begomovirus associated with leaf curl disease in chilli. World Journal of Pharmaceutical Research, 4(3): 1579-1592.

Senanayake, D. M. J. B., Mandal, B., Loha, S. and Verma, A., 2006, First report of Chilli leaf curl virus affecting chilli in India. New Disease Rep. 13 [http:// www.bspp.org.uk/ndr/July2006-35.asp]. Wagner, Georg, 2004, Vegetables' pests. Personal Communication. Schopperplatz 14, 4082 Aschach / Donau.

\section{How to cite this article:}

Sarkar, S., G.S. Sahu, S. Das, S.K. Dash, A. Nandi and Patnaik, A. 2018. Management of Chilli Leaf Curl Virus Disease in the Coastal Zone of Odisha through Integrated Approach. Int.J.Curr.Microbiol.App.Sci. 7(04): 132-140. doi: https://doi.org/10.20546/ijcmas.2018.704.015 